\title{
Antenatal diagnosis of steroid sulphatase deficiency: case report and literature survey
}

\author{
ROY A SHERWOOD, BERNARD F ROCKS \\ From the Biochemistry Department, Royal Sussex County Hospital, Brighton, East Sussex BN2 5BE
}

SUMMARY Steroid sulphatase deficiency is a recently recognised genetically determined inborn error of metabolism. Originally identified as an enzyme disorder of the placenta (commonly termed placental sulphatase deficiency), it is now known that the progeny of affected pregnancies have a generalised steroid sulphatase deficiency and that the enzyme defect persists throughout life. The disorder is characterised clinically by markedly low maternal oestrogen excretion in the presence of normal fetal growth and development. The importance of antenatal diagnosis lies in the differentiation of this disorder from the more ominous fetal defects that result in low oestrogen concentrations. This paper summarises the relevant literature and describes a case in which biochemical tests were used for the antenatal diagnosis of steroid sulphatase deficiency. The pregnancy resulted in a healthy baby boy delivered vaginally after a spontaneous labour.

The use of serum and urine oestriol measurements in the management of high-risk pregnancies is now well established. Nearly all of the oestriol present in the maternal serum or urine is derived from placental conversion of steroid precursors produced by the fetus. Therefore, maternal serum or urine oestriol concentrations reflect, primarily, the status of the fetoplacental unit. Very low third trimester oestriol levels have been associated with several clinical situations $^{1-3}$ : (a) iatrogenic effects (antibiotics, cortisone and other drugs), $(b)$ gross disturbances of the maternal enterohepatic circulation, $(c)$ severe intrauterine growth retardation, $(d)$ anencephaly, $(e)$ fetal death, $(f)$ primary fetal adrenal hypoplasia and (g) placental steroid sulphatase deficiency (SSD). Conditions $(a)$ to $(e)$ may be differentiated by the history and clinical examination. However, the latter two situations, $(f)$ and $(g)$ are more difficult to distinguish from one another. Fetal adrenal hypoplasia is associated with a high neonatal mortality rate as the newborn infants are likely to be at risk from adrenal insufficiency. In pregnancies with SSD there is a high incidence of difficult labourmany requiring caesarean section. Both conditions result in very low oestrogen production in the presence of apparently normal fetal growth and development. Fortunately, biochemical tests are useful in discriminating between these two conditions and the following case study illustrates their use.

Accepted for publication 13 April 1982

\section{Case report}

A 25-year-old primigravida failed to gain weight $\overrightarrow{0}$ during the 31st and 32nd weeks of pregnancy. Tif 24-hour urinary oestrogen output was found to be low. and she was admitted for further investigation. Apd from the oestrogens, routine blood (albumin, total protein, electrolytes, urea, calcium, phosphate, liver function tests and creatinine) and urine (protein, glucose and creatinine clearance) investigations were normal. Serial urinary oestrogens over a five-day $\overrightarrow{\vec{a}}$ period were consistently low (average concentration $7 \mu \mathrm{mol} / 24 \mathrm{~h}$, reference range $40-150 \mu \mathrm{mol} / 24 \mathrm{~h}$ ). The patient continued to be clinically normal with a very active fetus and began to gain weight again. A serum oestriol at $34 \mathrm{wk}$ was $10.7 \mathrm{nmol} / \mathrm{l}$ (reference range

Table 1 Concentration of steroid sulphates in maternal urine by capillary gas-liquid chromatography

\begin{tabular}{|c|c|c|c|}
\hline $\begin{array}{l}\text { Steroid sulphate } \\
(\mu \mathrm{mol} / 24 h)\end{array}$ & Patient & $\begin{array}{l}S S D \\
(n=I 0)\end{array}$ & $\begin{array}{l}\text { Normal } \\
(n=I 0)\end{array}$ \\
\hline $16 \alpha$-hydroxy DHA & $29 \cdot 99$ & $29 \cdot 57$ & $\begin{array}{l}1 \cdot 76 \\
(0 \cdot 39-4 \cdot 9)\end{array}$ \\
\hline 16-oxo-androstenediol & $5 \cdot 21$ & $5 \cdot 95$ & $\begin{array}{l}(0 \cdot 74 \\
(0 \cdot() 5-4 \cdot 8)\end{array}$ \\
\hline 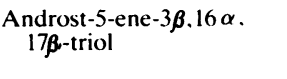 & $17 \cdot 05$ & $18 \cdot 55$ & $\begin{array}{l}1 \cdot 41 \\
(0 \cdot 16-7 \cdot(0)\end{array}$ \\
\hline 16,18-dihydroxy DHA & $1 \cdot(03$ & $6 \cdot 86$ & $(0 \cdot 16$ \\
\hline Oestriol & $1 \cdot 76$ & $1 \cdot 14$ & $17 \cdot 25$ \\
\hline $16 \alpha$-hydroxypregnenolone & $2 \cdot 31$ & 9.91 & $\begin{array}{l}(0) 33 \\
(0 \cdot 06-1 \cdot 38)\end{array}$ \\
\hline 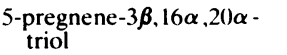 & $1 \cdot 22$ & $2 \cdot 0$ & ND \\
\hline
\end{tabular}

$\mathrm{DHA}=$ dehydroepiandrosterone

$\mathrm{ND}=$ not determined . 
26-28 nmol/l) and a serum placental lactogen (HPL) concentration of $7.5 \mathrm{mU} / \mathrm{l}$ (reference range $4-9 \mathrm{mU} / \mathrm{l}$ ) indicated normal placental function. Measurement of the biparietal diameter of the fetal head, using ultrasound, revealed a normal fetal growth rate. At this stage fetal adrenal hypoplasia or placental steroid sulphatase deficiency was suspected. Maternal urinary 17-oxogenic steroids were relatively high, 55 $\mu \mathrm{mol} / 24 \mathrm{~h}$ (reference range $15-56 \mu \mathrm{mol} / 24 \mathrm{~h}$ ) suggesting that SSD rather than fetal adrenal hypoplasia was the probable cause of the low oestrogen excretion. ${ }^{+}$The patient was sent home pending confirmation of the diagnosis.

The excretion of steroid sulphates in maternal urine (Table 1) was raised when compared with normal pregnancies (gas chromatographic determination by $\mathrm{Dr} \mathrm{J}$ Honour at the Clinical Research Centre, Harrow), but it was within the laboratory ranges for these compounds in 10 previous cases of confirmed SSD. ${ }^{5}$

Further oestriol determinations between 37 and 39 weeks were all less than $20 \mu \mathrm{mol} / 24 \mathrm{~h}$ and the pregnancy progressed normally.

At $39 \mathrm{wk}$ gestation the patient was readmitted to hospital with regular contractions and ruptured membranes. She gave birth to a $3310 \mathrm{~g}$ boy after a four-hour labour. The infant had an Apgar score of 9 at 1 minute and appeared healthy. The post-natal course was uneventful and mother and child were discharged five days later.

The mother's previous medical history was unremarkable but her brother has a dry scaly skin condition (? ichthyosis) which the family believe to be inherited from her great-grandfather. The child's progress is being followed to see if he develops this condition.

\section{Discussion}

Placental oestrogens are produced by the metabolism of dehydroepiandrosterone sulphate (DHAS) originating from the mother and the fetus, and $16 \alpha-$ hydroxydehydroepiandrosterone sulphate (16OHDHAS), originating predominantly from the fetus. In the first step of oestriol synthesis the sulphated conjugates are hydrolysed through the action of the microsomal enzyme $3 \beta$-yl steroid sulphatase (sterol sulphate sulphohydrolase, EC 3.1.6.2.). In the case of deficient activity of this enzyme the hydrolysis cannot take place and the formation of oestriol is impaired. ${ }^{\circ}$

The first case of SSD-then recognised as a placental sulphatase deficiency - was reported by France and Liggins in 1969. ${ }^{7}$ It was first assumed that the deficiency was extremely rare but in recent years reports have become more frequent and the literature now contains descriptions of 66 cases. ${ }^{57810-2327}$ Apart from the low oestrogen production no other manifestations directly attributable to the sulphatase deficiency have been reported during the antenatal period nor in the infant at birth. However, some groups have observed a high incidence of pregnancies of greater than 40 wk duration. ${ }^{10} 11151621$ This may be a feature of the disorder related to the fact that a high percentage of patients require medical or surgical intervention to facilitate delivery.

Less than one third of the pregnancies affected by SSD ended in spontaneous labour. The majority of cases required induction of labour, caesarean section, or both. Twenty-seven cases required caesarean section, $5 \times 1012-1618-2127$ eleven after induction had failed $^{512131516202127}$ while in eight cases induction was successful, ${ }^{5101214}$ although three of these required forceps delivery because of fetal distress. ${ }^{5}{ }^{5}$ Several cases terminated by caesarean section have been associated with an unripened cervix which failed to dilate on oxytocin administration. ${ }^{13141820}$ It has been postulated that the difficulties in achieving spontaneous labour and delivery may be due to the low oestrogen production. ${ }^{13}$ This suggests that high levels of oestrogens are necessary in preparing for and initiating labour. The low success rate of oxytocin induction and the relatively high incidence of unfavourable cervices suggest a blunting of the normal physiological responses of pregnancy.

Many different biochemical tests have been used to aid in the antenatal diagnosis of SSD. Several groups

Table 2 Biochemical findings in fetoplacental steroid sulphatase deficiency

\begin{tabular}{|c|c|c|c|}
\hline Sample & Substance & Finding & References \\
\hline \multirow[t]{4}{*}{ Maternal urine } & 17-oxogenic steroids & $\begin{array}{l}\text { High } \\
\text { normal }\end{array}$ & 4 \\
\hline & 17-oxosteroids & Raised & 19 \\
\hline & Pregnanediol & Normal & $13.14,19,21$ \\
\hline & Pregnanetriol & Normal & 12 \\
\hline \multirow[t]{9}{*}{ Maternal plasma } & Progesterone & Normal & 18 \\
\hline & Progesterone & Low & 14,19 \\
\hline & $17 \beta$-oestradiol & Low & 14 \\
\hline & $\begin{array}{l}\text { 17-hydroxyprogesterone } \\
17 \beta \text {-hydroxycortico- }\end{array}$ & Low & 14 \\
\hline & steroid & Low & 14 \\
\hline & Corticosteroid & Jow & 14 \\
\hline & HPL & Normal & $8,16,17$ \\
\hline & $\mathrm{HCG}$ & Normal & 16,17 \\
\hline & Cortisol & Normal & 19 \\
\hline \multirow[t]{5}{*}{ Amniotic fluid } & Pregnanetriol & Raised & 14 \\
\hline & DHAS & Raised & 16,17 \\
\hline & DHA & Normal & 16,17 \\
\hline & Androstenedione & Normal & 16,17 \\
\hline & Testosterone & Normal & 16,17 \\
\hline \multirow[t]{2}{*}{ Cord blood } & 16-hydroxy DHAS & Normal & $13,15,16$ \\
\hline & DHÄS & Normal & $13,15,16$ \\
\hline
\end{tabular}

$\mathrm{HPL}=$ human placental lactogen.

DHA = dehydroepiandrosterone.

$\mathrm{HCG}=$ human chorionic gonadotrophin.

DHAS = dehydroepiandrosterone sulphate. 
have investigated maternal urine and plasma steroid content while others used amniotic fluid. The findings of these workers are summarised in Table 2. The most commonly used test for the diagnosis of SSD is a "dynamic" procedure-the DHAS loading test. ${ }^{710111315162127}$ For this test a solution containing DHAS (50-250 mg) is injected into the amniotic fluid or intravenously and the excretion of oestriol determined during the following 24-hour period. In a normal pregnancy the maternal urinary oestriol concentration rises by between 10 and $30 \mu \mathrm{mol} / 24 \mathrm{~h}$ depending on the amount of DHAS administered, as it is metabolised and removed through the maternal circulation. Measurement of plasma oestradiol $1 \mathrm{~h}$ and $3 \mathrm{~h}$ after infusion is equally suitable. ${ }^{16}$ In SSD pregnancies the placenta cannot convert DHAS to oestriol so the maternal urinary oestriol remains very low. The diagnostic significance of the test can be enhanced by administering a DHA load in the same way. As the metabolism of DHA to oestriol can proceed in the absence of the sulphatase enzyme the maternal oestrogen output should rise in both normal and SSD cases. ${ }^{713}$ Although this is a useful way of detecting SSD in vivo it has the major disadvantage of being invasive particularly when the DHAS is injected into the amniotic sac with consequent risk to the fetus.

To differentiate between SSD and fetal adrenal hypoplasia Oakey ${ }^{4}$ measured maternal urinary oestrogens and 17-oxogenic steroids during the third trimester. He concluded that oestrogen excretion less than $11.5 \mu \mathrm{mol} / 24 \mathrm{~h}$ and 17 -oxogenic steroids greater than $26 \mu \mathrm{mol} / 24 \mathrm{~h}$ were characteristic of pregnancies with SSD.

Recently Taylor and Shackleton ${ }^{5}$ have applied capillary gas chromatography to the assay of steroid monosulphate fractions of maternal and neonatal urine. They have demonstrated a characteristic profile of steroid sulphates in maternal urine which is diagnostic of SSD (Table 1). A similar method has been used by Phillipou et al. ${ }^{23}$ These methods would appear to be the best way of diagnosing SSD antenatally and are likely to gain more widespread use in the coming years as obstetricians and clinical chemists become more aware of this deficiency. Before these methods were available in vitro studies of the placenta's ability to hydrolyse isotopically labelled sulphated oestriol precursors were recommended for definitive proof of SSD. In the SSD cases reported so far the sulphatase activity has seldom been greater than $4 \%$ of the control placentae and is often undetectable.

Preliminary findings by McNaught and France ${ }^{25}$ suggest that the biochemical basis of SSD may be a defect in membrane-enzyme structure which prevents the normal function of the enzyme.
With the notable exception of two pregnancies with apparently low placental steroid sulphatase activity ${ }^{8}$ all the confirmed cases of SSD have resulted in male infants. In 1977 Shapiro et $a^{20}$ reported the association of SSD and X-linked ichthyosis. They demonstrated the absence of steroid sulphatase enzymes in cultured fibroblasts from a patient born of a pregnancy affected by placental SSD. This work has been confirmed both in a later study of five cases by Shapiro et al $^{9}$ and by the work of Jöbsis et al ${ }^{1021}$ on six cases in Holland. The skin of affected infants usually remains normal for the first 3-6 months of life, after which ichthyosis becomes recognisable and persists throughout the life of the individual. The ichthyosis itself appears to be caused by the deficiency of the enzyme arylsulphatase $\mathrm{C}$ in the epidermis, although its role in the process of keratinisation is still unknown. Ichthyosis has now been reported in $\vec{N}$ association with one-fifth of the cases of SSD. This association with a known X-linked disorder and the 을 very high male:female ratio strongly suggests that SSD is an X-linked disorder, although autosomal dominant transmission with sex-linked expression cannot be totally excluded. ${ }^{6}$

Many cases of SSD probably go undetected since affected pregnancies follow a normal antenatal course. It has been estimated that as many as one if 3000 pregnancies is affected..$^{26}$ Routine screening of all third trimester pregnancies for oestriol excretio would probably reveal many more cases of SSD anव perhaps other associated defects of steroid metabolism.

The finding of a consistently low maternal urinary or plasma oestriol in company with apparently $\overrightarrow{\vec{\rho}}$ normal fetal development should alert the chemical pathologist/biochemist to the possibility of SSD and the need for confirmatory tests.

We are grateful to Dr J Honour (Clinical Research Centre, Harrow), Dr JGH Cook and Professor C Riley (both of the Biochemistry Dept, Royal Sussex County Hospital, Brighton) for their constructive criticism of our draft manuscript. We also thank $\mathrm{Mr}$ Measday (Consultant Obstetrician, RSCH, Brighton) for permission to report this case.

\section{References}

'Beischer NA, Brown JB. Current status of oestrogen assays in obstetrics and gynaecology. Obstet Gynecol Surv 1972;27:30343.

2 Trolle D, Bock JE, Gaede P. The prognostic and diagnostic value of total oestriol in urine and in serum and of HPL in serum in the last part of pregnancy. Am J Obstet Gynecol 1976;126:834-44.

${ }^{3}$ Wilde CE, Oakey RE. Biochemical tests for the assessment of fetoplacental function. Ann Clin Biochem 1975;12:83-118. 
+ Oakey RE. Placental sulphatase deficiency: antepartum differential diagnosis from foetal adrenal hypoplasia. Clin Endocrinol 1978;9:81-8.

s Taylor NF, Shackleton CHL. Gas chromatographic steroid analysis for diagnosis of placental sulphatase deficiency: a study of nine patients. J Clin Endocrinol Metab 1979;49:78-86.

"France JT. Steroid sulphatase deficiency. J Steroid Biochem 1979;11:647-51.

' France JT, Liggins GC. Placental sulphatase deficiency. J Clin Endocrinol Metab 1969;29:138-41.

${ }^{\times}$Mango DA, Montemurro A, Scirpa P. Bompiani A, Menini E. Four cases of pregnancy with low oestrogen production due to placental enzyme deficiency. EurJ Obstet Gynaecol Reprod Biol 1978;8:65-71.

- Shapiro LJ, France JT, Weiss R, Webster D. X-linked ichthyosis due to SSD. Lancet 1978;I:70-2.

i'. Jöbsi AC.De Groot WP, Tigges AJ et al. X-linked ichthyosis and $\mathrm{X}$-linked placental sulphatase deficiency: a disease entity. $A m J$ Pathol 1980;99:279-90.

" Cedard L, Tchobrousky C, Guglielmina R, Mailhac M. Insuffisance oestrogenique paradoxale au cours d'une grossesse normale par defaut de sulphatase placentaire. Bull Fed Soc Gynecol Obstet Lan Fr 1971;23:16-20.

'2 Fliegner JRH, Schindler I, Brown JB. Low urinary oestriol excretion during pregnancy associated with placental sulphatase deficiency or congenital adrenal hypoplasia. Journal of Obstetrics and Gynaecology of the British Commonwealth 1972;79:810-5.

13 France, JT, Seddon RJ, Liggins GC. A study of a pregnancy with low oestrogen production due to placental sulphatase deficiency. J Clin Endocrinol Metab 1973;36:1-9.

${ }^{14}$ Oakey RE, Cawood ML. MacDonald RR. Biochemical and clinical observations in a pregnancy with placental sulphatase and other enzyme deficiencies. Clin Endocrinol 1974;3:131-48.

is Tabei T, LeRoy Heinrichs W. Diagnosis of placental sulfatase deficiency. Am J Obstet Gynecol 1976;124:409-14.

${ }^{10}$ Osathanondh R, Canick J, Ryan KJ, Tulchinsky D. Placental sulphatase deficiency: a case study. J Clin Endocrinol Metab 1976;43:208-14.
17 Braunstein GD, Ziel FH, Allen A, Van de Velde R. Wade ME. Prenatal diagnosis of placental steroid sulphatase deficiency. Am J Obstet Gynecol 1976;126:716-9.

${ }^{1 *}$ Chadwick JM, Murnain JR. Placental sulphatase deficiency causing low urinary oestriol excretion in pregnancy complicated by toxaemia. Aust NZ J Obstet Gynecol 1976;16:119-20.

${ }^{14}$ Beastall GH, Kelly AM, England P. Rao LGS. MacGregor MW Paterson ML. Urinary oestrogen and plasma human placental lactogen as initial screening tests for a placental sulphatase deficiency. Scott Med J 1976;21:106-8.

2" Shapiro LJ, Cousins L. Fluharty AL. Stevens RL. Kihara H Steroid sulphatase deficiency. Pediatr Res 1977;11:894-7.

"1 Koppe JG, Marinkovic-Ilsen A, Rijken Y. De Groot WP. Jöbsis AC. X-linked ichthyosis: a sulphatase deficiency. Arch Dis Child 1978;53:803-6.

$\because$ Grose DJ. Placental sulphatase deficiency with spontaneous labour. Aust NZ Obstet Gynecol 1979;19:148-9.

${ }^{23}$ Phillipou G, Seamark RF, Sweet R. Prenatal diagnosis of placental sulphatase deficiency. Aust NZ J Obstet Gynaecol 1979:19:2336.

${ }^{24}$ De Groot WP, Jöbsis AC, Marinkovic-Ilsen A, Koppe JG, De Bruijn HWA. Sex-linked ichthyosis and placental sulphatase C deficiency. BrJ Dermatol 1980;103:73-9.

25 McNaught RW. France JT. Studies on the biochemical basis of steroid sulphatase deficiency: preliminary evidence suggesting a defect in membrane-enzyme structure. J Steroid Biochem 1980;13:363-73.

${ }^{26}$ France JT. Placental sulphatase deficiency. Reviews in perinatal medicine 1981:4:247-72.

${ }^{27}$ Bedin M, Alsat E, Tanguy G, Cedard L. Placental sulphatase deficiency. Clinical and biochemical study of 16 cases. Eur J Obstet Gynec Reprod Biol 1980;10:21-34.

Requests for reprints to: Dr BF Rocks, Biochemistry Department, Royal Sussex County Hospital, Eastern Road, Brighton, East Sussex, BN2 5BE, England. 